\title{
PERLINDUNGAN HUKUM ATAS PELEPASAN HAK MILIK ATAS TANAH BERDASARKAN UNDANG-UNDANG NOMOR 5 TAHUN1960 TENTANG UNDANG-UNDANG POKOK AGRARIA
}

\author{
Baiq Ishariaty Wika Utary \\ Akademi Sekretari Dan Manajemen Mataram \\ luisadi645@gmail.com
}

Tujuan penelitian ini Untuk mengetahui dan memahami Kebijakan Pemerintah dalam hal pengadaan tanah untuk kepentingan masyarakat berdasarkan peraturan perundang-undangan yang berlaku;Untuk mengetahui dan memahami kendala-kendala yang muncul dalam pelepasan hak atas tanah tersebut,Untuk mengetahui dan memahami perlindungan hukum bagi pemegang hak milik atas tanah yang mengalami kerugian akibat rendahnya pembayaran ganti kerugian oleh Pemerintah. Jenis penelitian yang digunakan adalah penelitian empirik.pendekatan yang digunakan pendekatan perundang-undangan dan pendekatan konseptual. Jenis dan sumber data, data primer dan data sekunder. Teknik pengumpulan data yaitu studi kepustakaan dan studi lapangan.

Tanah merupakan salah satu sarana kebutuhan yang amat penting dalam pengadaan tanah untuk kepentingan umum tidaklah mudah untuk dipecahkan. mengingat konsep pembangunan Indonesia pada dasarnya menggunakan konsep pembangunan berkelanjutan. Pembangunan yang berkelanjutan merupakan standar yang tidak hanya ditujukan bagi perlindungan lingkungan, melainkan juga bagi kebijakan pembangunan, artinya dalam penyediaan, penggunaan, peningkatan kemampuan sumber daya alam dan peningkatan taraf ekonomi, perlu menyadari pentingnya pelestarian fungsi lingkungan hidup, kesamaan derajat antar generasi, kesadaraan akan hak dan kewajiban masyarakat, pencegahan terhadap pembangunan yang merusak dan tidak bertanggung jawab terhadap lingkungan serta kewajiban untuk turut serta dalam melaksanakan pembangunan berkelanjutan pada setiap lapisan masyarakat.

Menurut Ahmad Husein Hasibuan ada 3 (tiga) kendala yang terdapat dalam pelaksanaan pembebasan tanah: faktor psikologis masyarakat dan faktor dana. Kendala yang merupakan faktor psikologis masyarakat adalah :

1) Masih ditemui sebagian pemilik/yang menguasai tanah beranggapan Pemerintah tempat bermanja-manja meminta ganti-rugi, karenanya meminta ganti-rugi yang tinggi, tidak memperdulikan jiran/tetangga yang bersedia menerima ganti-rugi yang dimusyawarahkan;

2) Masih ditemui pemilik yang menguasai tanah beranggapan pemilikan tanahnya adalah mulia dan sakral, sehingga sangat enggan melepaskannya walau dengan ganti-rugi, karenanya mereka bertahan meminta ganti-rugi yang sangat tinggi;

3) Kurangnya kesadaran pemilik/yang menguasai tanah tentang pantasnya mengutamakan kepentingan umum daripada kepentingan sendiri. Selanjutnya, kendala yang merupakan faktor dana adalah keterbatasandana pembebasan tanah sehingga tidak mampu membayar ganti kerugian dengan harga wajar menurut pasar umum setempat.

Kata Kunci: Perlindungan hukum, pelepasan hak milik tanah 


\section{PENDAHULUAN}

Indonesia merupakan negara

hukum dan bukan negara kekuasaan, yang berarti bahwa dalam setiap kegiatan kenegaraan selalu berdasarkan hukum yang berlaku. Oleh karena itu, maka dalam setiap tindakannya negara selalu menggunakan Undang-Undang sebagai acuan dari setiap tindakannya termasuk dalam penguasaan negara terhadap sumber daya alam. Negara menguasai seluruh sumber daya alam yang ada baik itu tanah, air bahkan ruang angkasa dan digunakan untuk kemakmuran rakyat. Hal tersebut tercermin pada Pasal 33 ayat (3) UUD Negara Republik Indonesia Tahun 1945, yaitu: "Bumi dan air dan kekayaan alam yang terkandung di dalamnya dikuasai oleh negara dan dipergunakan untuk sebesar-besarnya kemakmuran rakyat". Pasal 33 ayat (3) UUD Negara Republik Indonesia Tahun 1945 ini diimplementasikan lagi dalam UU No. 5 Tahun 1960 tentang Ketentuan Pokok Agraria. Di dalam penjelasan umum Undang-Undang Nomor 5 Tahun 1960 tentang Ketentuan Pokok Agraria disebutkan bahwa di dalam negara Republik Indonesia yang susunan kehidupan rakyatnya termasuk perekonomiannya, masih bercorak agraria, bumi, air dan ruang angkasa sebagai karunia Tuhan Yang Maha Esa mempunyai fungsi yang amat sangat penting untuk membangun masyarakat yang adil dan makmur sebagai yang dicita-citakan. Di dalam Undang-Undang Nomor 5 Tahun 1960 bahwa bumi, air dan ruang angkasa termasuk kekayaan alam yang terkandung didalamnya memiliki hubungan dengan negara yang bersifat abadi. Di mana negara memiliki hak menguasai atas pengelolaan dan pemanfaatannya demi hajat hidup orang banyak.

Dalam hal pengelolaan dan pemanfaatan tanah untuk kepentingan umum, negara memiliki hak untuk melakukan pengadaan atas tanah dengan cara pelepasan hak dari pemilik aslinya dengan membayar ganti kerugian. Dalam rangka pembangunan untuk kepentingan umum tersebut, pemerintah awalnya mengeluarkan aturan hukum berupa Keppres No. 55 Tahun 1993 tentang Pengadaan Tanah Bagi Pelaksanaan Pembangunan Untuk Kepentingan Umum jo Peraturan Menteri Negara Agraria/Kepala Badan Pertanahan Nasional Nomor 1 Tahun 1994 tentang Ketentuan Pelaksanaan Keppres No. 55 Tahun 1993 tentang Pengadaan Tanah Bagi Pelaksanaan Pembangunan Untuk Kepentingan Umum, yang kemudian dirubah dengan Perpres No. 36 Tahun 2005 tentang Pengadaan Tanah Bagi Pelaksanaan Pembangunan Untuk Kepentingan Umum. Adapun pengertian Pengadaan Tanah terdapat dalam Pasal 1 angka (3) PP No. 36 Tahun 2005, yaitu:"Pengadaan tanah adalah setiap kegiatan untuk mendapatkan tanah dengan cara memberikan ganti rugi kepada yang melepaskan atau menyerahkan tanah, bangunan, tanaman, dan benda-benda yang berkaitan dengan tanah atau dengan pencabutan hak atas tanah".UU No. 36 Tahun 2005 tersebut memperhatikan berbagai segi, baik mengenai tafsiran "untuk kepentingan umum" maupun proses pelaksanaannya dengan mengingat asas perlindungan dan kepastian hukum hak milik tanah dan benda-benda yang ada di atasnya. Pencabutan hak-hak atas tanah dan benda-benda yang ada di atasnya hanya dapat dilakukan dengan undangundang apabila benar-benar untuk kepentingan umum, dalam keadaan terpaksa dan sangat mendesak demi kepentingan umum/ Negara dan pembayaran ganti rugi yang adil dan bijaksana sesuai dengan ketentuan peraturan perundang-undangan yang berlaku. 
Dengan berlakunya UndangUndang Nomor 32 Tahun 2004 tentang Pemerintahan Daerah dan mengalami perubahan dengan berlakunya UU No. 12 Tahun 2008 tentang Pemerintahan Daerah, telah menambah kewenangan yang dimiliki oleh daerah dan bertambah juga tanggung jawab yang diemban oleh pemerintah daerah. Dengan bertambahnya kewenangan daerah, tuntutan dan kesiapan serta tanggung jawab daerah untuk melaksanakan kewenangan tersebut menjadi bertambah pula, oleh karena itu daerah harus menyiapkan sumber daya manusia, sumber daya keuangan, sarana, dan prasarana guna menghadapi tuntutan yang diberikan oleh Undang-Undang tersebut. Pemerintah daerah menyerahkan sebagian urusan untuk langsung diurus oleh Pemerintah Daerah berdasarkan desentralisasi. Hal mengenai penyerahan sebagian kekuasaan dari Pemerintah ke Pemerintah Daerah telah diungkapkan oleh Pipin Syarifin dalam bukunya yang berjudul Pemerintah Daerah di Indonesia, yaitu:"penyerahan", oleh karena itu penyerahan merupakan sifat pemberian kewenangan kepada daerah otonom menurut asas desentralisasi karena segala kebijaksanaan, perencanaan dan pembiayaan diserahkan sepenuhnya kepada daerah otonom. Pada asasnya makin lama makin banyak tugas pemerintah yang didesentralisasikan kepada daerah secara berangsurangsur sesuai dengan makin meningkatnya kemampuan daerah sebagai hasil pembangunan. Konsekuensinya, semakin banyak banyak urusan yang harus diserahkan kepada daerah kabupaten, kota sebagai urusan rumah tangganya.

Pemberian kewenangan penyelenggaraan pemerintahan dari

1 Pipin Syarifin dan Dedah Jubaedah, Pemerintah Daerah Di Indonesia, Bandung, Pustaka Setia, 2005, hlm. 98.
Pemerintah kepada Pemerintah Daerah didasarkan atas asas desentralisasi yang merupakan wujud dari otonomi yang luas, nyata, dan bertanggung jawab. Dalam menyelenggarakan urusan pemerintahan yang menjadi kewenangan Pemerintah Daerah dalam hal mengurus rumah tangganya sendiri baik dalam bidang pembangunan, pemerintahan, dan kemasyarakatan yang bertujuan untuk meningkatkan kesejahteraan masyarakat, pelayanan umum dan dayasaing daerah. Menurut Soehino hak untuk mengatur dan mengurus rumah tangga biasanya disebut otonomi yang berarti berhak untuk mengatur dan mengurus rumah tangganya sendiri atas inisiatif sendiri serta atas pembiayaan sendiri. ${ }^{2}$

Hal ini dapat dilihat pada Pasal 2 ayat (2) Undang-Undang No. 32 Tahun 2004 tentang Pemerintah Daerah yaitu:"Pemerintahan daerah sebagaimana dimaksud pada ayat (1) mengatur dan mengurus sendiri urusan pemerintahan menurut asas otonomi dan tugas pembantuan."Salah satu kewenangan yang dimiliki Pemerintah Daerah yaitu dapat melakukan tindakan pengadaan guna pemenuhan kebutuhan barang milik daerah baik itu pemenuhan kebutuhan fasilitas, sarana dan prasarana yang berupa barang bergerak atau barang tidak bergerak (tanah). Selain pemenuhan kebutuhan barang milik daerah, pengadaan juga dapat berupa jasa yang diberikan oleh pemerintah pusat, pemerintah daerah lainnya atau pihak lain yang mengikatkan diri dengan melakukan kerjasama dengan pemerintah daerah tersebut. Pengelolaan Barang Milik Daerah ini telah diatur dalam Peraturan Daerah Provinsi Nusa Tenggara Barat Nomor 8 Tahun 2007 tentang Pengelolaan Barang Milik Daerah yang merupakan rujukan dari Peraturan

2 Soehino, Asas-Asas Hukum Tata Pemerintahan, Yogyakarta, Liberti Yogyakarta, 1984, hlm. 185. 
Pemerintah Nomor 6 Tahun 2006 tentang Pengelolaan Barang Milik Negara/ Daerah yang isinya hampir sama hanya penempatan pasal dan beberapa tambahan yang disesuaikan dengan kebutuhan daerah tersebut. Mengenai pengadaan ini telah diatur didalam Pasal 1 ayat 23 Peraturan Daerah Provinsi Nusa Tenggara Barat No. 8 Tahun 2007 tentang Pengelolaan Barang Milik Daerah Yaitu:"Pengadaan adalah kegiatan untuk melakukan pemenuhan kebutuhan barang milik daerah dan jasa."

Barang Milik Daerah sebagai kekayaan daerah perlu dikelola secara tertib, efektif dan efisien sehingga dapat didayagunakan secara optimal dalam mendukung penyelenggaraan pemerintahan, pembangunan dan pelayanan kepada masyarakat.

Pemerintah Daerah harus melakukan pengadaan tanah untuk sarana jalan berdasarkan peraturan perundangundangan yang terkait seperti PP No. 36 Tahun 2005 tentang Pengadaan Tanah Bagi Pelaksanaan Pembangunan Untuk Kepentingan Umum, PP No. 6 Tahun 2006 tentang Pengelolaan Barang Milik Negara/Daerah dan Perda Prov. NTB No. 8 Tahun 2007 tentang Pengelolaan Barang Milik Daerah sebagai landasan dalam setiap kebijakan dalam hal pelepasan hak atas tanah tersebut.

Selain itu Pemerintah Daerah harus memperhatikan mekanisme pengadaan tanah sesuai dengan berbagai peraturan perundangundangan yang berlaku, seperti pemberian ganti kerugian yang sesuai dan lain sebagainya. Dalam pelaksanaannya pelepasan tanah oleh Pemerntah Daerah masih banyak terdapat tanah yang belum di sertifikat karena "masyarakatnya masih belum mengerti akan pentingnya sertifikasi tanah" serta kurangnya ganti kerugian yang diberikan kepada pemilik tanah tersebut. Dengan belum adanya sertifikat terhadap tanah mereka maka terdapat permasalahan terhadap pengadaan tanah untuk sarana jalan serta jalan yang dilakukan oleh Pemerintah Daerah masih menyalah artikan kata penguasaan negara terhadap tanah yang terkandung dalam Pasal 33 ayat (3) UUD 1945 dengan mengakui secara sepihak tanah milik masyarakat yang tidak memiliki sertifikat, serta kecilnya ganti kerugian yang diberikan kepada pemilik tanah tersebut.

\section{PEMBAHASAN}

\section{A. Kebijakan Pemerintah dalam pelepasan hak atas tanah demi kepentingan umum}

Dalam melakukan pengadaan

tanah untuk pembangunan jalan, tentunya harus berdasarkan peraturan perundang-undangan yang berlaku. hal tersebut dikarenakan bahwa Indonesia merupakan negara hukum, di mana dalam setiap tindakan yang dilakukan oleh pemerintah terutama eksekutif harus selalu berdasarkan peraturan perundang-undangan yang berlaku seperti halnya dalam pengadaan tanah bagi pembangunan jalan. Dalam hal pengadaan tanah bagi pembangunan jalan ini tidak lepas dari hukum pertanahan karena pembangunan jalan ini dilakukan di atas sebidang tanah. Oleh karena itu Dasar Hukum Pengadaan tanah bagi pembangunan jalan harus memperhatikan hierarki peraturan perundang-undangan yang berlaku.

Adapun dalam peraturan perundangundangan terdapat suatu landasan serta asas yang harus diperhatikan dalam setiap pembentukan peraturan perundang-undangan. dengan adanya suatu landasan dan asas dalam peraturan perundang-undangan diharapkan peratuan perundangundangan tersebut tidak bertentangan satu dengan lainnya dalam pembentukannya.

1. Landasan Peraturan Perundangundangan 
Setiap peraturan perundangundangan dapat dikatakan baik (good legislation), sah menurut hukum (legal validity) dan berlaku efektif karena dapat diterima secara wajar dan berlaku untuk waktu yang panjang, sehingga dilandaskan pada peruturan perundangundangan. Sudah banyak para ahli hukum yang memberikan argumentasi tentang peraturan perundang-undangan, antara lain $M$. Solly Lubis yang menyatakan bahwa ada 3 (tiga) landasan peraturan perundangundangan, yakni: ${ }^{3}$

a. Landasan Filosofis, yaitu landasan filsafat atau pandangan ide yang menjadi dasar cita-cita sewaktu menuangkan hasrat dan kebijaksanaan (pemerintah) ke dalam suatu rencana atau draft peraturan negara, misalnya Pancasila menjadi dasar filsafat perundang-undangan. Pada prinsipnya tidak dibuat bertentangan dengan Pancasila tersebut

b. Landasan Yuridis, ialah ketentuan hukum yang menjadi dasar hukum bagi pembuatan suatu peraturan. Misalnya UUD 1945 menjadi landasan yuridis untuk menjadi undang-undang organik. Selanjutnya Undang-Undang itu menjadi landasan yuridis bagi pembuatan peraturan pemerintah/ Perda.

c. Landasan Politis, ialah garis kebijakan politik yang menjadi dasar selanjutnya bagi kebijakankebijakan dan pengarahan ketatalaksanaan pemerintahan negara.

Disamping itu juga kita mengenal adanya landasan sosiologis (sociologische grondslag) dalam setiap pembuatan peraturan perundang-

${ }^{3}$ M. Solly Lubis, Landasan dan Teknik Perundang-undangan, Bandung, Mandar Maju 1989, halaman 77-78 undangan dikatakan mempunyai landasan sosiologis, apabila ketentuanketentuannya sesuai dengan keyakinan umum dan kesadaran masyarakat. Hal ini penting agar peraturan perundangundangan yang dibuat ditaati oleh masyarakat, dan tidak menjadi hurufhuruf mati belaka. Atas dasar sosiologis ini diharapkan suatu peraturan perundang-undangan yang dibuat akan diterima oleh masyarakat secara wajar bahkan diterima secara spontan. Peraturan perundang-undangan yang diterima secara wajar akan mempunyai daya berlaku efektif dan tidak begitu banyak memerlukan pengerahan institusional untuk melaksanakannya karena kaidah hukum berlaku berdasarkan penerimaan dari masyarakat tempat hukum itu berlaku.

Disamping landasan tersebut ada juga landasan yang lain dalam pembentukan peraturan perundangundangan yakni landasan ekonomis (economische grondslag). Landasan ini sangat efektif dan bersifat fakultatif. Artinya ia bisa ada kalau materi muatan yang diatur dalam suatu peraturan perundang-undangan yang mengatur masalah-masalah yang berkaitan dengan perekonomian. Misalnya apa yang menjadi tuntutan ekonomi masyarakat, kebutuhan-kebutuhan ekonomi masyarakat dan negara yang berupa Undang-Undang Nomor 25 Tahun 2007 Tentang Penanaman Modal, yang memberikan landasan ekonomi dalam konsiderannya, yakni dalam rangka menciptakan kedaulatan ekonomi nasional.

2. Asas-asas Peraturan perundangundangan

Di samping landasan peraturan perundang-undangan, juga dikenal asas-asas peraturan perundangundangan atau asas-asas hukum dalam pembentukan peraturan perundangundangan, yakni nilai-nilai yang dijadikan pedoman dalam penuangan norma atau isi peraturan ke dalam bentuk peraturan perundang-undangan 
yang diinginkan, dengan menggunakan metode yang tepat dan mengikuti prosedur yang telah ditentukan. Menurut Logemann, setiap peraturan hukum pada hakekatnya dipengaruhi oleh 2 (dua) unsur penting, yaitu: ${ }^{4}$

a. Unsur Riil, karena sifatnnya yang konkret bersumber dari lingkungan tempat manusia hidup, seperti tradisi atau sifat-sifat dibawa manusia sejak lahir dengan perbedaan jenisnya.

b. Unsur Idiil, karena sifatnya yang abstrak, bersumber pada diri manusia itu sendiri yang berupa akal pikiran dan perasaan.

Unsur-unsur yang mempengaruhi aturan hukum ini sesungguhnya lebih dapat disebut asas. Oleh karena bangunan hukum yang diinginkan pada dasarnya bersumber pada perasaan manusia disebut asas-asas sedangkan bangunan hukum yang bersumber pada akal pikiran manusia disebut pikiranpikiran. Pengertian asas hukum dalam pembentukan peraturan perundangundangan menurut Hamid S. Attamimi ialah untuk melihat benang merah dari sistem hukum positif yang ditelusuri. Asas-asas hukum ini dijadikan sebagai patokan-patokan pembentuk peraturan perundang-undangan agar tidak melenceng dari cita hukum (rechtsidee) yang telah disepakati bersama. Namun secara teoritikal asas-asas hukum bukanlah aturan hukum, sebab asasasas hukum tidak dapat diterapkan secara langsung terhadap suatu peristiwa konkret dengan menganggapnya sebagai bagian dari norma hukum. Meskipun demikian asasasas hukum tetap diperlukan dalam pembentukan peraturan perundangundangan karena hukum tidak dapat dimengerti tanpa asas-asas hukum.

${ }^{4}$ Abu Daud Busroh dan H. Abu Bakar Busroh, Asas-Asas Hukum Tata Negara, Jakarta, Galia Indonesia, 1998, halaman 12
Dari uraian di atas setidaknya terdapat 3 (tiga) fungsi asas hukum, yaitu: ${ }^{5}$

1. Sebagai patokan dalam pembentukan dan/atau pengujian norma hukum;

2. Untuk memudahkan kedekatan pemahaman terhadap hukum;

3. Sebagai cermin dari peradaban masyarakat bangsa tertentu dalam memandang perilaku.

Dalam proses pembentukan dan pengujian peraturan perundangundangan asas-asas yang diperlukan dapat digolongkan menjadi dua golongan asas-asas yaitu asas materil dan asas asas formil. Adapun pembagian masing-masing asas tersebut adalah sebagai berikut: 6

a. Asas-asas formal yang meliputi:

1. asas tujuan yang jelas;

2. asas perlunya pengaturan;

3. asas organ atau lembaga yang tepat;

4. asas materi muatan yang tepat;

5. asas dapat dilaksanakan;

6. asas dapat dikenali.

b. Asas-asas materil yang meliputi:

1. asas sesuai dengan cita hukum Indonesia dan norma fundamental negara;

2. asas sesuai dengan hukum dasar negara;

3. asas sesuai dengan prinsipprinsip negara berdasar atas hukum;

5 Hamid S. Attamimi, Peranan Keputusan Presiden Republik Indonesia Dalam Penyelenggaraan Pemerintahan Negara, Suatu Studi Analisis Keputusan Presiden Yang Berfungsi Pengaturan Dalam Kurun Waktu Repelita I, Disertasi Untuk Memperoleh Gelar Doktor Dalam Ilmu Hukum Pada Fakultas Hukum, Universitas Indonesia, Jakarta, 1990, halaman 302

6 I Gde Pantja Astawa, Dinamika Hukum dan Ilmu Perundang-undangan di Indonesia, PT. Alumni, Bandung, 2008, halaman 83-84 
4. asas sesuai dengan prinsip-prinsip pemerintahan berdasarkan sistem konstitusi

Dalam setiap peraturan perundang-perundangan harus terdapat asas-asas yang melandasi terbentuknya peraturan tersebut. Asas ini dijadikan patokan atau landasan terbentuknya norma-norma hukum yang ada dalam suatu peraturan tertentu. Asas-asas dalam suatu peraturan perundangundangan bersifat prinsip dan fundamental sehingga menjadi satukesatuan dengan norma-norma hukum yang terdapat dalam peraturan perundang-undangan. Namun asasasas dalam peraturan perundangundangan tidak dapat dijadikan patokan atau dasar pertimbangan untuk menjatuhkan suatu hukuman, karena pada prinsipnya di dalam asas tidak mengandung unsur-unsur yang terdapat dalam norma-norma hukum.

\section{B. Kendala-kendala yang timbul dalam pengadaan tanah yang digunakan untuk kepentingan masyarakat}

Tanah mempunyai peranan penting dalam hidup dan kehidupan masyarakat diantaranya sebagai prasarana dalam bidang Perindustrian, Perumahan, Jalan. Tanah dapat dinilai sebagai benda tetap yang dapat digunakan sebagai tabungan masa depan. Tanah merupakan tempat pemukiman dari sebagian besar umat manusia, disamping sebagai sumber penghidupan bagi manusia yang mencari nafkah melalui usaha tani dan perkebunan, yang akhirnya tanah juga yang dijadikan persemayaman terakhir bagi seorang yang meninggal dunia. ${ }^{7} \mathrm{Di}$ sisi lain tanah harus dipergunakan dan dimanfaatkan sebesar-besarnya untuk kesejahteraan rakyat secara adil dan merata, juga harus dijaga

\footnotetext{
${ }^{7}$ Abdurrahman, Masalah Hak-Hak Atas Tanah dan Pembebasan Tanah di Indonesia, cet. 2, (Bandung : Alumni, 1983) hal. 1.
}

kelestariannya. ${ }^{8}$ Tanah merupakan salah satu sarana kebutuhan yang amat penting dalam pengadaan tanah untuk kepentingan umum tidaklah mudah untuk dipecahkan. ${ }^{9}$ mengingat konsep pembangunan Indonesia pada dasarnya menggunakan konsep pembangunan berkelanjutan. Pembangunan yang berkelanjutan merupakan standar yang tidak hanya ditujukan bagi perlindungan lingkungan, ${ }^{10}$ melainkan juga bagi kebijakan pembangunan, artinya dalam penyediaan, penggunaan, peningkatan kemampuan sumber daya alam dan peningkatan taraf ekonomi, perlu menyadari pentingnya pelestarian fungsi lingkungan hidup, kesamaan derajat antar generasi, kesadaraan akan hak dan kewajiban masyarakat, pencegahan terhadap pembangunan yang merusak dan tidak bertanggung jawab terhadap lingkungan serta kewajiban untuk turut serta dalam melaksanakan pembangunan berkelanjutan pada setiap lapisan masyarakat. ${ }^{11}$

Menurut Ahmad Husein Hasibuan ada 2 (dua) kendala yang terdapat dalam pelaksanaan pembebasan tanah: faktor psikologis masyarakat dan faktor dana. Kendala yang merupakan faktor psikologis masyarakat adalah :12Masih ditemui sebagian pemilik/yang menguasai tanah beranggapan Pemerintah tempat

8 Achmad Rubaie, Hukum Pengadaan Tanah Untuk Kepentingan Umum, (Malang:

Bayumedia Publishing, 2007), hal 1

${ }^{9}$ I Wayan Suandra, Hukum Pertanahan Indonesia, cet. 1, (Jakarta : PT. Rineka Cipta, 1994) hal. 11.

${ }^{10}$ Alvi Syahrin, Pengaturan Hukum dan

Kebijakan Pembangunan Perumahan dan

Pemukiman Berkelanjutan, (Medan : Pustaka Bangsa Press 2003), Hal 1

11 Koesnadi Hardjasoemantri, Hukum Tata Lingkungan, (Yogyakarta :Gajah Mada

University Press 1999) Hal 18-19.

12 Ahman Husein Hasibuan. Masalah Perkotaan Berkaitan dengan Urbanisasi dan Penyediaan

Tanah. Makalah 1986 : Hal. 6-7. 
bermanja-manja meminta ganti-rugi, karenanya meminta ganti-rugi yang tinggi, tidak memperdulikan jiran/tetangga yang bersedia menerima ganti-rugi yang dimusyawarahkan;Masih ditemui pemilik yang menguasai tanah beranggapan pemilikan tanahnya adalah mulia dan sakral, sehingga sangat enggan melepaskannya walau dengan ganti-rugi, karenanya mereka bertahan meminta ganti-rugi yang sangat tinggi; Kurangnya kesadaran pemilik/yang menguasai tanah tentang pantasnya mengutamakan kepentingan umum daripada kepentingan sendiri. Selanjutnya, kendala yang merupakan faktor dana adalah keterbatasandana pembebasan tanah sehingga tidak mampu membayar ganti kerugian dengan harga wajar menurut pasar umum setempat.

Menurut Pasal 1 angka 1 Keppres No.55/1993 yang dimaksud dengan Pengadaan Tanah adalah setiap kegiatan untuk mendapatkan tanah dengan cara memberikan ganti kerugian kepada yang berhak atas tanah tersebut. Jadi dapat disimpulkan bahwa pengadaan tanah dilakukan dengan cara memberikan ganti kerugian kepada yang berhak atas tanah tersebut, tidak dengan cara lain selain pemberian ganti kerugian. Dan menurut Pasal 1 angka 3 Perpres No.36/2005 yang dimaksud dengan Pengadaan Tanah adalah setiap kegiatan untuk mendapatkan tanah dengan cara memberikan ganti kerugian kepada yang melepaskan atau menyerahkan tanah, bangunan, tanaman dan bendabenda yang berkaitan dengan tanah atau dengan pencabutan hak atas tanah.

\section{C. perlindungan hukum bagi pemegang hak milik atas tanah yang mengalami kerugian akibat rendahnya pembayaran ganti kerugian oleh Pemerintah Daerah}

Penguasaan terhadap bumi, air dan luar angkasa dikuasai oleh negara. Namun penguasaan, pemilikan, penggunaan, dan pemanfaatan tanah dapat dilakukan oleh seluruh warga Negara Indonesia baik perorangan maupun badan hukum berdasarkan fungsi sosial. Hak atas tanah ini harus memiliki kepastian hukum bagi para pemilik tanah dengan memiliki sertifikat atau sejenisnya yang telah didaftarkan sesuai dengan pengelolaan tanah tersebut. Kepastian hukum mengenai hak-hak atas tanah sebagaimana yang dicita-citakan oleh UUPA mencakup tiga hal, yaitu kepastian mengenai obyek hak atas tanah; kepastian mengenai subyek hak atas tanah dan kepastian mengenai status hak atas tanah. Khususnya mengenai kepastian obyek hak atas tanah, secara teknis hal ini menuntut adanya sifat "keunikan" setiap bidang tanah yang bersangkutan. Keunikan inilah yang menghindarkan dari berbagai sengketa tanah yang bersumber pada sengketa batas dan letak bidang tanah. Oleh karena itu, kepastian mengenai objek ini harus mempu menunjukkan secara jelas kepada semua pihak tentang batas, luas dan letak dari bidang tanah yang bersangkutan. Untuk memberikan kepastian yang demikian diperlukan infrastruktur yang memadai sehingga bidang tanah yang ada di lapangan dapat digambarkan pada peta dan surat ukur secara benar. Dalam kaitannya ini, kendala terbesar yang dihadapi adalah besarnya biaya untuk membangun infrastruktur, yaitu berupa titik-titik dasar teknik sebagai referensi pengukuran bidang tanah; dan peta-peta dasar sebagai media penggambaran bidang tanah tersebut. ${ }^{13}$

Kekuasaan negara atas tanah yang tidak dipunyai dengan sesuatu hak oleh seseorang atau pihak lainnya adalah lebih luas dan penuh. Negara dapat memberikan tanah kepada

\footnotetext{
13 Adrian Sutedi, Politik dan Kebijakan Hukum Pertanahan Serta Berbagai Permasalahannya, BP. Cipta Jaya, Jakarta, 2006, hlm. 38.
} 
seseorang atau badan hukum dengan sesuatu hak menurut peruntukan dan keperluannya, misalnya hak milik, hak guna usaha, hak guna bangunan atau hak pakai dan hak-hak lainnya. Hal tersebut dapat dilihat pada Pasal 16 ayat (1) UU No. 5 Tahun 1960, yaitu:

a. hak milik,

b. hak guna usaha,

c. hak guna bangunan,

d. hak pakai,

e. hak sewa,

f. hak membuka tanah,

g. hak memungut hasil hutan,

h. hak-hak lain yang tidak termasuk dalam hak-hak tersebut di atas yang akan ditetapkan dengan undangundang serta hak-hak yang sifatnya sementara sebgai yang disebutkan dalam pasal 53

Hak-hak atas tanah tersebut dapat diberikan oleh negara kepada perseorangan ataupun badan hukum untuk dimanfaatkan secara maksimal dan dapat memberikan kesejahteraan bagi masyarakat banyak. Hak atas tanah bersumber dari hak menguasai negara atas tanah dapat diberikan kepda perseorangan baik warga negara Indonesia. Menurut Soedikno Mertokusumo, wewenang yang dipunyai oleh pemegang hak atas tanah terhadap tanahnya dibagi menjadi 2 , yaitu: ${ }^{14}$

1. wewenang umum

wewenang yang bersifat umum yaitu pemegang hak atas tanah mempunyai wewenang untuk menggunakan tanahnya, termasuk juga tubuh bumi dan air dan ruang yang ada di atasnya.

2. wewenang khusus

wewenang yang bersifat khusus yaitu pemegang hak atas tanah mempunyai wewenang untuk menggunakan tanahnya sesuai dengan macam hak atas tanahnya. hlm. 45.
Hak milik merupakan hak asli yang dimiliki oleh setiap WNI yang didapatkan melalui pembelian ataupun harta warisan yang didapatkan oleh orang tuanya. Hak milik terhadap tanah ini dapat dialihkan karena kepada orang lain dengan cara menjual atau menyewakannya kepada orang atau badan hukum lainnya. Hal tersebut dapat dilihat pada Pasal 20 UU No. 5 Tahun 1960, yaitu(1)hak milik adalah hak turun temurun, terkuat dan terpenuh yang dapat dipunyai orang atas tanah, dengan mengingat ketentuan dalam Pasal 6, (2) Hak milik dapat beralih dan dialihkan kepada orang lain. Sifat dari hak milik yang membedakannya dengan hak atas tanah lainnya adalah hak yang terkuat dan terpenuhi, maksudnya untuk menunjukkan bahwa diantara hak-hak atas tanah yang dipunyai oleh orang, hak miliklah yang paling kuat dan penuh. Hal tersebut dikarenakan orang yang memiliki hak milik terhadap tanah dapat melalukan apa saja terhadap pengelolaan terhadap tanah tersebut. Hak milik ini biasanya didapatkan melalui pembagian harta warisan yang diturunkan kepadanya untuk dapat dikelola sesuai dengan peruntukan dan keinginan dari si pemilik tanah tersebut.

Adapun subyek hukum yang dapat mendapatkan hak milik terdapat dalam Pasal 21 UU No. 5 Tahun 1960, yaitu:

(1) Hanya warganegara Indonesia dapat mempunyai hak milik;

(2) Oleh Pemerintah ditetapkan badanbadan hukum yang dapat mempunyai hak milik dan syaratsyaratnya;

(3) Orang asing yang sesudah berlakunya Undang-Undang ini memperoleh hak milik karena pewarisan tanpa wasiat atau percampuran harta karena perkawinan, demikian pula warganegara Indonesia yang mempunyai hak milik dan setelah berlakunya undang-undang ini kehilangan kewarganegaraannya 
wajib melepaskan hak itu di dalam jangka waktu satu tahun sejak diperolehnya hak tersebut atau hilangny kewarganegaraan itu. Jika sesudah jangka waktu tersebut lampau hak milik itu tidak dilepaskan, maka hak tersebut hapus karena hukum dan tanahnya jatuh pada Negara, dengan ketentuan bahwa hak-hak pihak lain yang membebaninya tetap berlangsung.

(4) Selama seseorang di samping kewarganegaraan Indonesianya mempunyai kewarganegaraan asing maka ia tidak dapat mempunyai tanah dengan hak milik dan baginya berlaku ketentuan dalam ayat (3) pasal ini.

Berdasarkan ketentuan di atas maka yang berhak untuk memiliki hak milik adalah warganegara Indonesia asli serta badan hukum yang telah memenuhi persyaratan yang ditentukan oleh pemerintah. Sedangkan orang asing tidak dapat memiliki hak milik terhadap tanah yang ada di Indonesia walaupun ia mendapatkan warisan tetap saja tanah tersebut akan dikuasai oleh Negara sebagaimana yang telah ditentukan dalam UUPA. Hal tersebut dimaksudkan untuk menjaga persatuan dan kesatuan NRI, yang apabila orang asing dapat memiliki tanah di Indonesia maka akan menimbulkan gejolak dalam system pemerintahan, dimana terdapat suatu kepemilikan tanah oleh orang asing di dalam NRI.

Hak milik ini diperoleh melalui turun temurun berdasarkan harta kekayaan keluarga dari seseorang. Selain diperoleh melalui warisan secara turun temurun, hak milik terhadap tanah ini dapat diperoleh melalui penetapan pemerintah serta ketentuan UndangUndang terhadap badan hukum yang ingin memiliki sebidang tanah atas nama perusahaannya tersebut yang didapatkan sesuai dengan ketentuan yang telah ditentukan. Pemindahan hak milik juga dapat dilakukan dengan jual beli, penukaran, penghibahan dan lain sebagainya. hal tersebut dapat dilihap pada Pasal 26 UU No. 5 Tahun 1960, yaitu(1)jual-beli, penukaran, penghibahan, pemberian dengan wasiat, pemberian menurut adat dan perbuatan-perbuatan lain yang dimaksud untuk memindahkan hak milik serta pengawasannya diatur dengan Peraturan Pemerintah,

(2)setiap jual-beli, penukaran, penghibahan, pembelian dengan wasiat dan perbuatan-perbuatan lain yang dimaksudkan untuk langsung atau tidak langsung memindahkan hak milik kepada orang asing, kepada seorang warganegara yang disamping kewarganegaraan Indonesianya mempunyai kewarganegaraan asing atau kepada suatu badan hukum, kecuali yang ditetapkan oleh Pemerintah termaksud dalam pasal 31 ayat (2), adalah batal karena hukum dan tanahnya jatuh kepada Negara, dengan ketentuan, bahwa hak-hak pihak lain yang membebaninya tetap berlangsung serta semua pembayaran yang telah diterima oleh pemilik tidak dapt dituntut kembali.

Seseorang yang memiliki hak milik atas tanah harus mendaftarkan tanahnya. Pendaftaran tanah ini merupakan alat pembuktian yang kuat terhadap kepemilikan tanah dari orang tersebut. Demikian pula dlam setiap peralihan, hapusnya serta pembebanan dari tanah harus tetap didaftarkan guna memberikan kepastian hukum terhadap tanah tersebut. Dalam Pasal 19 ayat (2), pendaftaran tanah tersebut meliputi:
a. pengukuran perpetaan dan pembukuan tanah;
b. pendaftaran hak-hak atas tanah dan peralihan hak-hak tersebut;
c. pemberian surat-surat tanda bukti hak, yang berlaku sebagai alat pembuktian yang kuat.
Pendaftaran tanah ini sangat penting sekali dilakukan demi tercapainya kepastian hukum dari 
kepemilikan tanah tersebut. Selain itu pendaftaran tanah dapat menghindarkan dari sengketa tanah yang banyak terjadi di kalangan masyarakat. Pendaftaran tanah ini diimplementasikan dengan diterbitkannya sertifikat oleh Kantor Pertanahan setempat. Hak milik ini dapat juga dijadikan jaminan utang dengan dibebani hak tanggungan, maksudnya adalah tanah milik yang dibebani hak tanggungan ini tetap di tangan pemiliknya, namun dalam hal pemilik tanah membutuhkan uang dapat menggadaikan tanahnya, dan dalam hal ini maka tanahnya tersebut beralih untuk sementara waktu kepada pemegang gadai sampai utangnya tersebut.

\section{Kesimpulan}

\section{PENUTUP}

1. Bahwa pengadaan tanah bagi pembangunan jalan harus dilakukan berdasarkan asas berkeadilan terutama dalam pemberian ganti kerugian terhadap para pihak yang tanahnya terkena penggusuran.

2. Bahwa struktur pelaksanaan pengadaan tanah bagi pembangunan jalan dalam Penetapan Ganti Kerugian dilakukan dengan cara musyawarah antara Instansi Pemerintah melalui Tim Pengelola Kegiatan dengan

\section{DAFTAR PUSTAKA}

\section{A. Buku}

Parlindungan, 1989, Hak

Pengelolaan Menurut Sistem UUPA, Bandung, Mandar Maju.

Adrian Sutedi, 2006. Politik dan Kebijakan Hukum Pertanahan Serta Berbagai Permasalahannya, BP. Jakarta, Cipta Jaya, masyarakat dengan melihat Nilai Jual Obyek Pajak tahun berjalan dan harga pasaran dimana letak obyek tanah tersebut dan hasilnya di dasarkan hasil musyawarah kesepakatan harga hal tersebut telah sesuai dengan Pasal 15 Peraturan Presiden Nomor 65 Tahun 2006 Jo Pasal 59 ayat (1), (2) Peraturan Kepala Badan Pertanahan Nasional Republik Indonesia Nomor 3 Tahun 2007, tentang Pengadaan tanah Bagi Pembangunan Untuk Kepentingan Umum.

3. Kendala-kendala yang timbul dalam pengadaan tanah untuk jalan adalah kurangnya dana dari pemerintah serta hambatan yang timbul dari warga yang tanahnya terkena proyek pembangunan jalan, adalah tidak ada kesepakatan mengenai nilai ganti ruginya yang diberikan oleh Pemerintah yang dianggap masih tidak layak. Sehingga masih ada sebagian warga yang menolak/tidak mau mengambil uang ganti ruginya. Menurut masyarakat mereka merasa dibohongi karena sesuai dengan apa yang disepakati besarnya pengganti.
Agus Salim Andi Gadjong, 2007. Pemerintahan Daerah, Kajian Politik dan Hukum, cet. Pertama,Jakarata, Ghalia Indonesia,

Amrah Muslimin, 1960.Ikhtisar Perkembangan Otonomi Daerah 1903-1978, Jakarta : Djambatan,

Anton M. Moeliono dkk, 1955. Kamus Umum Bahasa Idonesia, 
Cetakan I, Jakarta, Balai Pustaka,

B.N.Marbun, 2005.Otonomi Daerah 1945-2005 Proses dan Realita: Perkembangan Otda, sejak zaman Kolonial Belanda sampai saat ini, Cetakan I, Jakarta, Pustaka Sinar harapan,

Bagir Manan, 2000. "Arogansi MPR", Jakarta, Majalah Republika,

Edy Suasono dalam Istislam, 2000. Kebijakan dan Hukum Lingkungan Sebagai Instrumen Pembangunan Berwawasan Lingkungan dan Berkelanjutan, Arena Hukum, No. 10 Tahun 4, Maret,

Esmi Warrasih Pujirahayu, 2005 Pranata Hukum Sebuah Telaah Sosiologis, Semarang,Suryandaru Utama.

Herbert A Simons, 1984. Perilaku Administrasi (terjemahan), Cetakan I, Jakarta PT. Bina Aksara,

Indroharto, 1991. Usaha memahami undang-undang tentang peradilan tata usaha negara, Jakarta, sinar harapan,

Lawrence M. Friedman, Tahun 1984. American Law, New YorkLondon: W.W. Norton \& Company,

M. Irfan Islamy, 2002.Prinsip-Prinsip Perumusan Kebijaksanaan Negara, Jakarta, Bumi Aksara,

Maria Farida Indrati Soeprapto, 1998.IImu Perundangundangan; Dasardasar dan
Pembentukannya,

Yogyakarta, Kanisius,

Philipus M. Hadjon, 1998.Tentang Wewenang, Makalah dan Penataan Hukum Administrasi, Surabaya, Fakultas hukum UNAIR,

Pipin Syarifin dan Dedah Jubaedah, 2005. Pemerintah Daerah Di Indonesia, Bandung, Pustaka Setia,

SF. Marbun, 1997. Peradilan Administrasi Negara dan Upaya Administratif Di Indonesia, Jogjakarta, Liberty,

Soedikno Mertokusumo, 1988.Hukum dan Politik Agraria, Jakarta,Universitas Terbuka, Karunika,

Soehino, 1984.Asas-Asas Hukum Tata Pemerintahan, Yogyakarta, Liberti Yogyakarta,

Soejadi, 1999.Pancasila Sebagai Sumber Tertib Hukum Indonesia, Yogyakarta, Lukman Offset,

Soerjono Soekamto, 1988. Pokokpokok Sosiologi Hukum, Cetakan I, Jakarta, Rajawali Press,

Sumali, 2003.Reduksi Kekuasaan Eksekutif di Bidang Peraturan Pemerintah Pengganti Undang-Undang (Perpu), Malang, UMM Press,

Syamsul Hadi, 2009. Efektifitas Pelaksanaan Peraturan pemerintah Nomor 30 tahun 1980 Tentang Disiplin Pegawai Negeri Sipil (Studi 


\section{Di Kabupaten lombok Tengah) Tesis,}

Tresna R, Bertamasya Ketaman Ketatanegaraan,Dibya Bandung, tanpa tahun.

William Dunn, 1994.Analisis Kebijakan Publik, Yogyakarta, Gadjah Mada University Press,

B. Peraturan PerundangUndangan

Undang-Undang Dasar Negara Republik Indonesia Tahun 1945

UU No. 5 Tahun 1960 tentang Peraturan Dasar Pokok-Pokok Agraria (LN No. 104 Tahun 1960)

PP No. 6 Tahun 2006 tentang Penelolaan Barang Milik Daerah (Tambahan Lembaran Negara Republik Indonesia Nomor 4609)

Perpres No. 36 Tahun 2005 tentang Pengadaan Tanah Bagi Pelaksanaan Pembangunan Untuk Kepentingan Umum

Perda Prov. NTB No. 8 Tahun 2007 tentang Pengelolaan Barang Milik Daerah (Tambahan Lembaran Daerah Provinsi Nusa Tenggara Barat Nomor 27). 